\title{
Love Contracts in the Workplace
}

\author{
C. W. Von Bergen \\ Southeastern Oklahoma State University
}

Romance frequently occurs in the office but when workplace relationships dissolve, then accusations of poor judgment, breaches of ethics, favoritism, lost productivity, and sexual harassment grievances may occur. Such issues may be particularly troublesome for entrepreneurs and small businesses because capital is limited, and time, talent, and money diverted to issues surrounding workplace romance and possibly sexual harassment are especially problematic. To reduce firm liability for sexual harassment charges companies may want to consider adopting love contracts that memorialize the consensual nature of the relationship and that if the romance ends the employees will not sue the employer for harassment.

Keywords: workplace romance, work relationships, sexual harassment, firm liability

\section{INTRODUCTION}

In the last several decades the U.S. workplace has experienced increases in the number of women in the labor force, required hours on the job, work arrangements fostering social contact outside of work, and mixed-gender work teams. Such phenomena have led to higher incidences of workplace romance (e.g., Mano \& Gabriel, 2006; Pierce \& Aguinis, 2001; Powell, 2012). Indeed, the workplace appears to be a logical place for romantic relationships to develop because people who work together tend to have similar backgrounds, talents, and aspirations (Fisher, 1994). Interestingly, hierarchical workplace romances are more common than romances between employees of equal rank (Dillard, Hale, \& Segrin, 1994).

Workplace romances are considered relationships that happen "between two members of an organization where sexual attraction is present, affection is communicated, and both members recognize the relationship to be something more than just professional and platonic" (Horan \& Chory, 2011, p. 565). Nearly 10 million workplace romances develop annually (Spragins, 2004); moreover, about 40\% of employees have had a workplace romance (Parks, 2006). They represent approximately $33 \%$ of all romantic relationships in the U.S. (Bureau of National Affairs, 1988), and results from a survey of 617 human resource professionals suggest that their frequency has remained stable or increased in recent years (Society for Human Resource Management [SHRM], 1998). In a 2017 SHRM survey, 57\% of individuals responding said they engaged in a romantic relationship at work (Adams, 2018). According to an American Management Association Survey on Workplace Dating (2003), 12\% of all managers married someone they started dating at work. Of the 30\% who have dated at work, $44 \%$ report their dating resulted in marriage ( $12 \%$ of all respondents). Another $23 \%$, or $7 \%$ of the total, entered long-term relationships. In the U.S., contrary to popular belief, many workplace romances are sincere, love- 
motivated, long-term companionate or passionate relationships as opposed to short-lived flings or jobmotivated utilitarian relationships (Dillard et al., 1994; Pierce \& Aguinis, 2009).

\section{BENEFITS AND COSTS ASSOCIATED WITH WORKPLACE ROMANCE}

\section{Benefits}

Researchers have identified several benefits of workplace romance, including better job performance, increased job satisfaction, and enhanced job involvement and organizational commitment. Pierce (1998), for example, found that workplace romance was positively associated with one's job performance while Pierce and Aguinis (2003) indicated that participating in a satisfying workplace romance was correlated with one's overall job satisfaction. Studies have also noted that love-motivated workplace romances were positively associated with female participants' levels of job involvement (Dillard, 1987) and that participating in a workplace romance was positively related to organizational commitment (Pierce \& Aguinis, 2003). Such findings are consistent with Southwest Airlines' philosophy of encouraging workplace romances because they feel that such relationships can lead to enhanced morale and energy at work (Wylie, 2006). In addition to being allowed to date, employees are even permitted to ask out passengers if they are polite and do not do anything devious, like use a company database to mine personal information. "We encourage nepotism," declared Southwest spokesperson Linda Rutherford (cited in Feeney, 2004). Ben \& Jerry's is similarly supportive of workplace romance and makes no effort to limit personal relationships among employees. For instance, it hosts winter solstice parties for its employees, where it subsidizes hotel rooms to discourage drinking and driving. A human resources manager at the company indicated, "We expect that our employees will date, fall in love, and become partners. If a problem comes up, we encourage employees to let us know, and we'll talk about it" (Loftus, 1995 , p. 34).

\section{Costs}

While there may be benefits to workplace romance, there are also potential damages. Workplace romances are not illegal and not typically the target of litigation (Clark, 2006); nevertheless, large numbers of workplace romances end badly (Pierce \& Aguinis, 2009), resulting in problematic outcomes for firms. By far, the most significant concern employers voice is that one of the parties-typically the woman (Gutek, Cohen, \& Konrad, 1990; U.S. Merit Systems Protection Board, 1994)—will charge the company with sexual harassment (Pierce, Broberg, McClure, \& Aguinis, 2004) which can entail considerable costs including legal fees, expenses related to employee turnover, losses linked to team disruption, lower productivity from increased absences, and reduced motivation and commitment. Moreover, the current media spotlight on sexual harassment fostered by the \#MeToo movement and the list of well-known men accused inappropriate workplace sexual behavior (e.g., Harvey Weinstein, Bill Cosby, Brett Kavanagh, Al Franken) has raised the visibility of sexual harassment and created a cultural shift demanding increased culpability for workplace sexual harassment and assault (Carlsen et al., 2018; Shaw, Hegewisch, \& Hess, 2018). While most publicity focuses on large, familiar firms, illegal sexual conduct occurs in small and medium-sized firms too. Organizations that ignore the hazards associated with workplace sexual harassment risk financial and reputational destruction.

Another cost involves unethical firm behavior. Most firms strive to achieve ethical conduct among their employees (Trevino, Weaver, \& Reynolds, 2006). One means of examining ethical behavior involves Jones' (1991) framework, which indicates that an ethical or moral issue exists when an individual's voluntary actions harm or benefit another person. Based on this definition, an employee's participation in romantic behavior (or sexually harassing behavior) at work constitutes a moral act (O'Leary-Kelly \& Bowes-Sperry, 2001). According to Jones (1991), then, some types of workplace romances are perceived as unethical relationships. For example, this could include a married supervisor who has an extramarital fling with a subordinate or a subordinate who violates a company policy by having a romantic relationship with his or her supervisor solely to benefit their career (Mainiero, 2005). One study that examined approaches to career success found that some subordinates may try to create 
unfair advantages for themselves by participating in a hierarchical workplace romance as a covert careeradvancement strategy (Harris \& Ogbonna, 2006).

Another harm involves third party claims of sexual harassment based on favoritism. Indeed, supervisors have been known to show bias toward subordinate lovers by providing lighter workloads, promotions, pay raises, or other unique benefits that create dissension in the workgroup (Mainiero, 1986; Pierce et al., 1996). Sometimes, coworkers of the subordinate may bring third party claims based on a supervisor's real or perceived preference toward his or her lover. While such allegations charging disparate treatment and hostile work environment usually fail, claims regarding favoritism appear to be increasing (Willert \& Pedersen, 2006). The EEOC's position is that Title VII does not prohibit isolated instances of preferential treatment based upon consensual romantic relationships. An isolated example of favoritism toward a significant other in a workplace romance may be unfair, but it does not rise to the level of discrimination in violation of Title VII, since both men and women are disadvantaged for reasons other than their gender. However, the EEOC has indicated that "widespread sexual favoritism," as opposed to "isolated sexual favoritism," may give rise to actionable claims.

A third problem area includes the right to privacy. Nevertheless, the constitutionally guaranteed right to privacy does not appear to protect individuals involved in intimate relationships at work (Hallinan, 1993) because employers can require workers to disclose information about close relationships that involve actual or perceived conflicts of interest. Failure to communicate can be legal grounds for discharge (Segal, 1993). Additionally, courts have demonstrated sympathy for the plight of employers facing problems arising from fraternization between employees. They recognize that workplace romances can have a tangible and often negative impact on a company's ability to achieve legitimate business objectives. At the same time, however, courts maintain respect for individual privacy rights of employees and will not allow trampling those rights beyond reason (Dworkin, 1997). Nonetheless, employees, particularly in the private sector, have few workplace privacy rights, and to prevail in an invasion of privacy claim, employees must have a reasonable expectation of privacy in a particular matter. As such, employers should give employees actual notice of any rule regarding office romantic relationships, whether through written policy or in a training session, to decrease or eliminate liability on such a claim.

Another risk for organizations happens when such relationships culminate in break-ups at work that are disruptive to participants' and coworkers' job performance (Pierce \& Aguinis, 1997, 2001), including workplace violence. Accordingly, some employers cite fear of workplace violence as a justification for regulating employee relationships (Dean, 1996). Indeed, considering the prevalence of intimate partner violence on work premises (O'Leary-Kelly, Lean, Reeves, \& Randel, 2008), organizations must be prepared to manage retaliation violence (e.g., stalking, physical abuse that stems from soured romances). McDonald (2000) provides some chilling examples in his aptly named article, "Failed Workplace Romances: If You're Lucky, You'll Just Get Sued." He specifically cited the fatal-attraction-like case of Saret-Cook v. Gilbert, Kelly, Crowley \& Jennett (1999) involving a sexual harassment claim by a former paralegal suing after the end of her affair with a firm partner that virtually destroyed the lives of the two people involved.

Employers may legitimately fear that a work romance parting could create a job-site clash and the potential for workplace violence because a jealous or scorned romantic partner could bring a domestic dispute into the workplace (Schaner, 1994). Such fear may be well- founded: of the 700 to 1,100 workplace homicides annually in the United States, an estimated 31 percent involve intimate or personal relationships that have gone bad and resulted in feelings of betrayal (Singleton, 2008). Employees who feel that they have a positive, trusting romantic relationship with their manager have more extreme adverse reactions to a violation of trust than do employees who do not have such a relationship in the first place (Morrison \& Robinson, 1997). Their negative reactions are likely to be much stronger and more likely to include anger and other negative emotions (Eddleston, Kidder, \& Litzky, 2002). Thus, trust is a double-edged sword because the presence of it can enhance the relationship and increase performance but may also lead to more severe deviant behaviors when violated, including workplace violence (Litzky, Eddleston, \& Kidder, 2006). 
In summary, all too frequently, the public debate sparked by office romance have been polarized between those who say that sex does not belong in the workplace and those who argue that virtually "anything goes" as far as consenting adults are concerned (Stan, 1995). Both positions, in their extreme forms, are untenable. Sexual relationships at work are not always everlastingly liberating and mutually fulfilling, nor are they always sexually harassing and harmful. Individuals can and do make distinctions between sexual harassment and assault on the one hand, and pleasurable, mutually desired sexual interactions and relationships on the other (Williams, Giuffre, \& Dellinger, 1999).

Because office romance can have both positive and negative consequences, managers have a vital role to play fostering positive outcomes while intervening to minimize any negative repercussions. The management and legal literature generally support companies' power to regulate these relationships (Williams et al., 1999), and based on these considerations, some organizations are asking employees to sign a consensual relationship agreement often referred to as a love contract.

\section{LOVE CONTRACTS}

Legal liability for harassment for the employer occurs only in those cases in which the firm was negligent in instituting an anti-harassment policy and providing its employees an avenue to complain (524 U.S. 742 (1998)). It is not surprising that many employers have adopted overbroad policies that prohibit relationships between consenting adults, as well as sexually harassing behavior. One such effort organizations are considering are love contracts in which both parties acknowledge that they are willing participants in a relationship and that it is consensual and if it fails no legal action will be taken against the employer or the partner (Wilson, 2015). Generally, the agreements are a defense in sexual harassment suits more than anything else. The love contract serves as compelling evidence that the relationship was voluntary, that the employees were aware of the company's sexual harassment and retaliation policies and agreed to report any harassment or retaliation if the relationship ends. Moreover, the contract gives notice that the firm took steps to maintain a workplace free from sexual abuse.

They have been introduced, primarily in the United States, as an alternative to no-dating policies and to protect the employer against liability in possible claims of sexual harassment should the relationship break off. Beyond protecting themselves from sexual harassment lawsuits, there are several other reasons why employers are implementing such policies. These include protection against claims of retaliation once the relationship ends, preventing a decrease in employee morale and productivity and prevention of unprofessional behavior by employees. Such agreements often also stipulate that the liaison will not affect or interfere with the work of those involved. By signing such an agreement, the two employees involved acknowledge that (a) the romantic relationship is voluntary, desired, and unrelated to their professional relationship at work and that each person is free to terminate the romance at any time without any harmful consequences.

A love contract is basically an employer's recognition that certain employees are in an intimate or dating relationship with each other and that this condition is consented to by all parties. The agreement typically contains wording that describes who workers should turn to for help if sexual harassment or conflict arise. In other words, the love contract aims to help protect both the employer and employees from lawsuits caused by sexual harassment claims. When the couple signs this agreement, it is giving comfort to the organization that the employees in the relationship know the company's policies and that if the relationship stops, the workers can terminate it without fear that it will affect their career or work environment.

While a contract between two individuals appears unromantic, employers are increasingly seeing them as a way of protecting both the individuals involved and the company from discrimination claims. Though it may not prevent all litigation, a "love contract" will assist the company in defending claims. It confirms that neither person has been forced or threatened into a relationship. Any policy should apply to and be enforced uniformly among employees, regardless of marital status, gender, and sexual orientation, as well as other legally protected categories. It also establishes appropriate and professional office behavior during the relationship and after if it ends. A love contract requires reporting to human resources 
(HR) that the relationship is consensual and reporting to HR when the relationship ends. Employers also need to be careful about favoritism claims by other co-workers.

When presenting such a contract, it is imperative to meet separately with each employee involved. Both individuals should sign and commit to the love contract. Depending on the circumstances, some of the following provisions may be appropriate:

- Both individuals confirm the relationship has been and continues to be consensual and voluntary.

- The company's sexual harassment, retaliation, and other applicable policies are repeated and acknowledged. This may include a restatement of the company's zero-tolerance policy of harassment and discrimination.

- Both individuals agree that on-premises behavior should be professional and respectful of other employees.

- Both individuals will refrain from favoritism and conflicts of interest.

- Both individuals agree not to misuse company property, including, but not limited to, its computers, e-mail, voice mail, cell phones, or other devices.

- Both individuals acknowledge the company may monitor its property at any time.

- Both individuals agree to report any harassing conduct if the relationship ends.

- Both individuals agree to treat each other with respect if the relationship ends.

- Both individuals agree not to retaliate if the relationship ends at either individual's decision.

- Both individuals agree to notify HR if the relationship ends. This is important because it allows the employer to manage any behavior that could be construed as harassment after a status change.

- Both individuals acknowledge that they have had enough time to fully consider and understand the love contract, and to seek legal counsel before signing it (Parent, 2009).

This contract essentially allows the couple to continue their business and personal relationship but attempts to eliminate the employer's liability if a future sexual harassment charge is made (Schaefer \& Tudor, 2001) In the contract, both parties agree that the relationship is voluntary and does not violate the company's sexual harassment policy.

Given management's concern that any kind of external sexual manifestation at work is counterproductive (Powell, 1993), employee relations professionals are using the public's growing interest in sexual harassment to prevent consensual, welcomed sexual relationships as well. The current judicially created definition of sexual harassment sometimes covers instances in which the plaintiff consented to the relationship but felt coerced or did not welcome it (Meritor Savings Bank, FSB v. Vinson, 1986). Employers become anxious. because they view this broad definition of sexual harassment in conjunction with the possibility of being held vicariously liable for sexually harassing behavior committed by supervisors against employees (Rabin-Margalioth, 2006). The rationale that employers thus offer when they regulate their employees' sexual behavior is that they cannot distinguish between welcomed relationships from sexually harassing ones, that consensual relationships may culminate in sexual harassment claims, and that the U.S. Supreme Court encourages employers' self-regulation and inquiry into the sexual activity of their workers by recommending that employers institute an anti-sexual harassment policy with grievance procedures.

A typical love contract will often contain the following provisions: "We hereby notify the Company that we wish to enter into a voluntary and mutual consensual social relationship. In entering this relationship, we both understand and agree that we are both free to end the social relationship at any time. Should the social relationship end, we both agree that we shall not allow the breakup to impact the performance of our duties negatively. Before signing this Consensual Relationship Contract, we received and reviewed the Company Sexual Harassment Policy, a copy of which is attached hereto. By signing below, we acknowledge that the social relationship between us does not violate the Company's Sexual Harassment Policy, and that entering this social relationship has not been made a condition or term of employment" (Schaefer \& Tudor, 2001, p. 7). It might seem strange to have to go through all this hassle 
for what could turn out to be a meaningless relationship, but to many employers, it would seem strange not to.

\section{SUMMARY AND CONCLUSION}

Whether companies should even try to regulate workplace romance or pressure employees to sign consensual relationships to indemnify employers from future harassment charges is a matter of much philosophical, economic, and legal debate. Indeed, some scholars contend that organizations have gone overboard in regulating employees' sexual conduct (Clark, 2006; Rabin-Margalioth, 2006). Nevertheless, given the connection between dissolved workplace romances and sexually harassing behavior, it is recommended that managers or supervisors at least consider discussing the possibility of signing a love contract with employees who are involved in a workplace romance. The agreement should stipulate congenial terms and conditions that each party must abide by after a romantic dissolution. Examples of friendly terms and conditions might include no arguments at work; managing negative emotional states such as anger, resentment, or jealousy; relocating workspaces; and a willingness to be repeatedly informed of the organization's integrated workplace romance/sexual harassment policy.

The creation of love contracts requires firms to find the resources and means of enforcing it, and some believe that the enforcement difficulties outweigh the benefits (McNair Law Firm, 1996). Amaral (2006) suggests that firms consider several issues, including how much social monitoring it is ready to undertake? What procedures are currently in place or is it willing to develop? What financial and managerial time considerations will be required to enforce policies and procedures related to love contracts? When will the firm enforce the guidelines? What actions of the romantic partners be prohibited at work? What consequences will happen is the agreement is violated? What happens if employees refuse to sign such an agreement?

Once the employer determines that it must prohibit either romance between all employees or only between supervisor and subordinates, it must notify employees unambiguously and must enforce the rule consistently and evenhandedly. Disciplining only some couples or only the female or male partner will only invite lawsuits. There should also not be an exception for CEOs. Additionally, the prohibition should apply without regard to marital status regardless of the enforcer's moral values and perceptions. The firm cannot punish adulterers while allowing the conduct of unmarried persons. It constitutes discrimination based on marital status.

Inconsistent enforcement may give rise to disparate-treatment claims based on sex, race, or other prohibited bases such as marital status. At minimum, it may make the employer look bad in front of a jury should that happen (Segal, 2005).

Love contracts may assist employers avoid liability regarding sexual harassment charges, but firms must determine if the efforts involved in implementing such a policy are worth the energy involved. The firm should be aware that there are costs in terms of development, communication, and policy enforcement.

\section{REFERENCES}

Adams, T. (2018). Ask an Expert: Should Employers Establish a Policy on Romantic Relationships in the Office? Retrieved from https://www.shrm.org/hr-today/news/hr-magazine/0218/pages/shouldemployers-establish-a-policy-on-romanticrelationships.aspx

Amaral, H.P. (2006). Workplace Romance and Fraternization Policies. Seminar Research Paper Series. Paper 7. Retrieved from http://digitalcommons.uri.edu/lrc_paper_series/7

American Management Association. (2003, February 10). 2003 Survey on Workplace Dating. Retrieved from http://www. amanet.org/training/seminars/2003-Survey-on-Workplace-Dating-32.aspx

Bureau of National Affairs. (1988). Corporate affairs: Nepotism, office romance, \& sexual harassment. Washington, DC: BNA. 
Carlsen, A., Salam, M., Miller, C.C., Lu, D., Ngu, A., Patel, J.K., \& Wichter, Z. (2018, October 29). \#MeToo Brought Down 201 Powerful Men. Nearly Half of Their Replacements Are Women. New York Times. Retrieved from https://www.nytimes.com/interactive/2018/10/23/U.S./metooreplacements.html

Clark, L. (2006). Sexual relationships and sexual conduct in the workplace. Legal Studies, 26(3), 347368.

Dean, J.L. (1996). Employer regulation of employee personal relationships. Boston University Law Review, 76(5), 1051-1055

Dillard, J.P. (1987). Close relationships at work: Perceptions of the motives and performance of relational participants. Journal of Social and Personal Relationships, 4(2), 179-193.

Dillard, J.P., Hale, J.L., \& Segrin, C. (1994). Close relationships in task environments: Perceptions of relational types, illicitness, and power. Management Communication Quarterly, 7(3), 227-255

Dworkin, M. (1997). It's my life-leave me alone: Off-the-job employee associational privacy rights. American Business Law Journal, 35, 47-95.

Eddleston, K.A., Kidder, D.L., \& Litzky, B.E. (2002). Who's the boss? Contending with competing expectations from customers and management. Academy of Management Executive, 16(4), 85-95.

Feeney, S.A. (2004, February). When Office Love Goes Bad. Retrieved from http://www.workforce.com/archive/feature/23/62/31/index.php

Fisher, A.B. (1994). Getting comfortable with couples in the workplace. Fortune, 130(7), 138-143.

Gutek, B.A., Cohen, A.B., \& Konrad, A.M. (1990). Predicting social-sexual behavior at work: A contact hypothesis. Academy of Management Journal, 33(33), 560-577.

Hallinan, K.M. (1993). Invasion of privacy or protection against sexual harassment: Co-employee dating and employer liability. Columbia Journal of Law and Social Problems, 26, 435-464.

Harris, L.C., \& Ogbonna, E. (2006). Approaches to career success: An exploration of surreptitious career success strategies. Human Resource Management, 45(1), 43-65.

Horan, S.M., \& Chory, R.M. (2011). Understanding work-life blending: Credibility implications for those who date at work. Communication Studies, 62, 563-580.

Jones, T.M. (1991). Ethical decision making by individuals in organizations: An issue-contingent model. The Academy of Management Review, 16(2), 366-395.

Litzky, B.E., Eddleston, K.A., \& Kidder, D.L. (2006). The good, the bad, and the misguided: How managers inadvertently encourage deviant behaviors. The Academy of Management: Perspectives, 20(1), 91-103.

Loftus, M. (1995, March/April). Frisky business: Why love in the workplace is flourishing. Psychology Today, 28, 34-35.

Mainiero, L.A. (1986). A review and analysis of power dynamics in organizational romances. Academy of Management Review, 11(4), 750-762.

Mainiero, L.A. (2005). On the ethics of office romance: Developing a moral compass for the workplace In R.J. Burke \& M.C. Mattis (Eds.), Supporting women's career advancement: Challenges and opportunities (pp. 151-173). Northampton, MA: Edward Elgar.

Mano, R., \& Gabriel, Y. (2006). Workplace romances in cold and hot organizational climates: The experience of Israel and Taiwan. Human Relations, 59(1), 7-35.

McDonald, J.J., Jr. (2000). Failed workplace romances: If you're lucky you'll just get sued. Employee Relations Law Journal, 26(2), 101-111.

McNair Law Firm, P.A. (1996). Workplace romances and the lives they destroy. South Carolina Employment Law Letter, 5(1), 1.

Meritor Savings Bank, FSB v. Vinson, 477 U.S. 57, 67. (1986).

Morrison, E.W., \& Robinson, S.L. (1997). When employees feel betrayed: A model of how psychological contract violation develops. Academy of Management Review, 22(1), 226-256.

O'Leary-Kelly, A.M., \& Bowes-Sperry, L. (2001). Sexual harassment as unethical behavior: The role of moral intensity. Human Resource Management Review, 11(1-2), 73-92. 
O'Leary-Kelly, A.M., Lean, E., Reeves, C., \& Randel, J. (2008). Coming into the light: Intimate partner violence and its effects at work. Academy of Management Perspectives, 22(2), 57-72.

Parent, J.L. (2009, January 30-February 12). Taking out a contract on workplace romance. New Hampshire Business Review, p.27.

Parks, M. (2006, January). 2006 workplace romance poll findings (Report No. 06-0019). Alexandria, VA: Society for Human Resource Management.

Pierce, C.A. (1998). Factors associated with participating in a romantic relationship in a work environment. Journal of Applied Social Psychology, 28(18), 1712-1730.

Pierce, C.A., \& Aguinis, H. (1997). Bridging the gap between romantic relationships and sexual harassment in organizations. Journal of Organizational Behavior, 18(3), 197-299.

Pierce, C.A., \& Aguinis, H. (2001). A framework for investigating the link between workplace romance and sexual harassment. Group and Organization Management, 26(2), 206-229.

Pierce, C.A., \& Aguinis, H. (2003). Romantic relationships in organizations: A test of a model of formation and impact factors. Management Research, 1, 161-169.

Pierce, C.A., \& Aguinis, H. (2009). Moving beyond a legal-centric approach to managing workplace romances, organizationally sensible recommendations for HR leaders. Human Resource Management, 48(3), 447-464.

Pierce, C.A., Broberg, B.J., McClure, J.R., \& Aguinis, H. (2004). Responding to sexual harassment complaints: Effects of a dissolved workplace romance on decision-making standards. Organizational Behavior and Human Decision Processes, 95(1), 66-82.

Powell, G.N. (1993). Women and men in management (2nd ed.). Newbury Park, CA: Sage

Powell, G.N. (2012). Six ways of seeing the elephant: The intersection of sex, gender, and leadership. Gender in Management: An International Journal, 27, 119-141.

Rabin-Margalioth, S. (2006). Love at work. Duke Journal of Gender Law and Policy, 13(1), 237-253.

Saret-Cook v. Gilbert, Kelly, Crowley \& Jennett, 74 Cal. App. 4th 1211. (1999).

Segal, J.A. (1993). Love: What's work got to do with it? HR Magazine, 38, 37-41.

Segal, J.A. (2005). Dangerous liaisons. Alexandria, VA: Society for Human Resource Management.

Schaefer, C., \& Tudor, T.R. (2001). Managing workplace romances. SAM Advanced Management Journal, 66(3), 4-10.

Schaner, D.L. (1994). Romance in the workplace: Should employers act as chaperones? Employee Relations Law Journal, 20(1), 47-71.

Shaw, E., Hegewisch, A., \& Hess, C. (2018). Sexual Harassment and Assault at Work: Understanding the Costs. Institute for Women's Policy Research. Retrieved from https://iwpr.org/publications/sexual-harassment-work-cost/

Singleton, D. (2008, December 17). Experts: Many workplace killings have origin in romance. The Times-Tribune, p.B-1. Scranton, PA.

Society for Human Resource Management (SHRM). (1998). Workplace romance survey (Item no. 62. 17014). Alexandria, VA: SHRM Public Affairs Department.

Spragins, E. (2004, February). Dangerous Liaisons As Small Firms Relax Their Rules on Office Romances, Some Face Unexpected Consequences. Retrieved from http://money.cnn.com/magazines/fsb/fsb_archive/2004/02/01/360633/index.htm

Stan, A.M. (1995). Debating sexual correctness: Pornography, sexual harassment, date rape, and the politics of sexual equality. New York: Delta.

Trevino, L.K., Weaver, G.R., \& Reynolds, S.J. (2006). Behavioral ethics in organizations: A review. Journal of Management, 32(6), 951-990.

U.S. Merit Systems Protection Board. (1994). Sexual harassment in the federal workplace: Trends, progress, and continuing challenges. Washington, DC: U.S. Government Printing Office.

Willert, S.J., \& Pedersen, M.L. (2006). Corporate Affairs: An Employer's Guide to Restrictions on Workplace Relationships. Retrieved from http://www.williamskastner.com/uploadedFiles/WillertPedersenCorpAffairsFall06.pdf 
Williams, C.L., Giuffre, P.A., \& Dellinger, K. (1999). Sexuality in the workplace: Organizational control, sexual harassment, and the pursuit of pleasure. American Review of Sociology, 25, 73-93.

Wilson, F. (2015). Love is in the air: Romantic relationships at work. In R. Morrison \& H. CooperThomas (Eds.), Relationships in organizations: A work psychology perspective (pp. 8-27).

London: Palgrave Macmillan.

Wylie, I. (2006, January 14). Should Employers Encourage Office Relationships? The Guardian. Retrieved from http://www.guardian.co.uk/money/2006/jan/14/careers.work1 